\title{
Proses review film-film Indonesia oleh komunitas film Cine Crib
}

\author{
Sandi Jaya Saputra \\ Universitas Padjadjaran, Bandung, Indonesia
}

\begin{abstract}
ABSTRAK
Penelitian ini membahas mengenai proses Cine Crib dalam me-review film-film Indonesia. Cine Crib adalah komunitas film dengan jumlah subscribers YouTube tertinggi (216.000), yang digawangi Aria Gardhadipura, atau yang biasa dipanggil Aria. Kepopuleran Cine Crib saat ini tidak berbanding lurus dengan pemahaman khalayak terkait apa itu review, essay dan kritik film. Melalui penelitian ini, khalayak diharapkan mampu mendapatkan sebuah rujukan yang komprehensif dalam konteks review film. Tujuan penelitian ini adalah untuk memaparkan empat aspek proses review film-film Indonesia oleh Cine Crib, yaitu: (1) Bagaimana proses Cine Crib sebagai komunitas menentukan film yang akan di-review; (2) Bagaimana menentukan reviewer film; (3) Kaidah apa yang dipakai dalam me-review; dan (4) Bagaimana proses kurasi material video review yang memenuhi standar Cine Crib. Metode deskriptif kualitatif menjadi dipilih untuk memberikan pondasi dari semua tahapan yang dirancang berurut mengenai apa itu review film. Secara teoretis, penulis menggunakan pendekatan Planning, Organizing, Actuating dan Controlling (POAC) yang dicangkokkan dalam penelitian ini untuk melihat apakah Cine Crib bekerja secara terstruktur. Teknik pengumpulan data yang digunakan adalah kajian dokumen, wawancara dan observasi. Hasil yang ditemukan dalam penelitian ini antara lain: (1) Tidak ada tema khusus dalam me-review film, karena reviewer film diberikan kebebasan sesuai dengan ketertarikan masing-masing; (2) Aria selaku editor dan bisa dikatakan "kurator" tidak menentukan reviewer film; (3) Cine Crib memodifikasi teori umum dalam mengkaji atau mengkritik film sesuai kebutuhan dan kenyamanan reviewer film; dan (4) Aria menentukan proses editing dan kurasi material video review.
\end{abstract}

Kata-kata Kunci: Kajian film; Cine Crib; komunitas; review; YouTube

\section{Cine Crib process in reviewing Indonesian films as a film community}

\begin{abstract}
This study discusses the Cine Crib process in reviewing Indonesian films. Cine Crib is the film community with the highest number of YouTube subscribers (216,000), fronted by Aria Gardhadipura, as known as Aria. The current popularity of Cine Crib is not directly proportional to the audience's understanding of what reviews, essays and film criticisms are. Through this research, the audience is expected to be able to get a comprehensive reference in the context of film reviews. The purpose of this study is to describe four aspects of the review process for Indonesian films by Cine Crib, which are: (1) How does the Cine Crib process as a community determine which films will be reviewed; (2) How to determine the film reviewer; (3) What rules are used in reviewing; and (4) How to curate video review material that meets Cine Crib standards. The qualitative descriptive method was chosen to provide the foundation of all stages designed sequentially about what a film review is. Theoretically, the author uses the Planning, Organizing, Actuating and Controlling (POAC) approach which was grafted in this study to see if Cine Crib works in a structured manner. Data collection techniques used are document review, interviews and observations. The results found in this study include: (1) There is no specific theme in reviewing films, because film reviewers are given freedom according to their respective interests; (2) Aria as the editor and can be said as "curator" does not determine the film reviewer; (3) Cine Crib modifies general theory in reviewing or criticizing films according to the needs and convenience of film reviewers; and (4) Aria determines the process of editing and curating the video review material.
\end{abstract}

Keywords: Film studies; Cine Crib; community; review; YouTube

Korespondensi: Sandi Jaya Saputra, S.I.Kom., M.Sn. Fakultas Ilmu Komunikasi Universitas Padjadjaran. J1. Raya Bandung Sumedang KM 21, Jatinangor 45363.Email: sandi.jaya.saputra@unpad.ac.id 


\section{PENDAHULUAN}

Review atau ulasan adalah diksi yang dipilih oleh Cine Crib sebagai pintu masuk dalam menelaah film, khususnya dalam konteks ini adalah me-review film Indonesia. Me-review film Indonesia dipilih sebagai positioning oleh Cine Crib sebagai bentuk kegelisahan mereka melihat perkembangan produksi film Indonesia. Pada deskripsi channel YouTube Cine Crib terpampang jelas kalimat "We review movies weekly, all kind of movies, especially Indonesian movies. Don't forget to subscribe for new review every week!"

Cine Crib adalah komunitas yang digagas oleh Aria Gardhadipura yang biasa dipanggil Aria, seorang seorang reviewer yang aktif menulis di blog-nya sejak 2009. Cine Crib adalah sinonim dari MTV Cribs, sebuah acara yang memperkenalkan rumah artis tersohor dengan cukup santai dan "apa adanya" semangat itu yang coba hadirkan dalam Cine Crib dalam setiap review nya. Cine Crib tercetus dari sahabat Aria bernama Adriano Rudiman, 2016 Beralih ke channel YouTube dan mengajak beberapa teman lainnya yang memiliki ketertarikan dan visi yang sama terhadap film (Gardhadipura, 2021).

Saat ini channel YouTube Cine Crib menjadi salah satu yang terbesar dalam kategori reviewer, dengan 216.000 subscribers (Crib, 2021). Hal ini pula yang menjadi salah satu mendasari penulis membedah komunitas film Cine Crib, ketimbang channel YouTube lainnya. Popularitas yang ditandai dengan jumlah

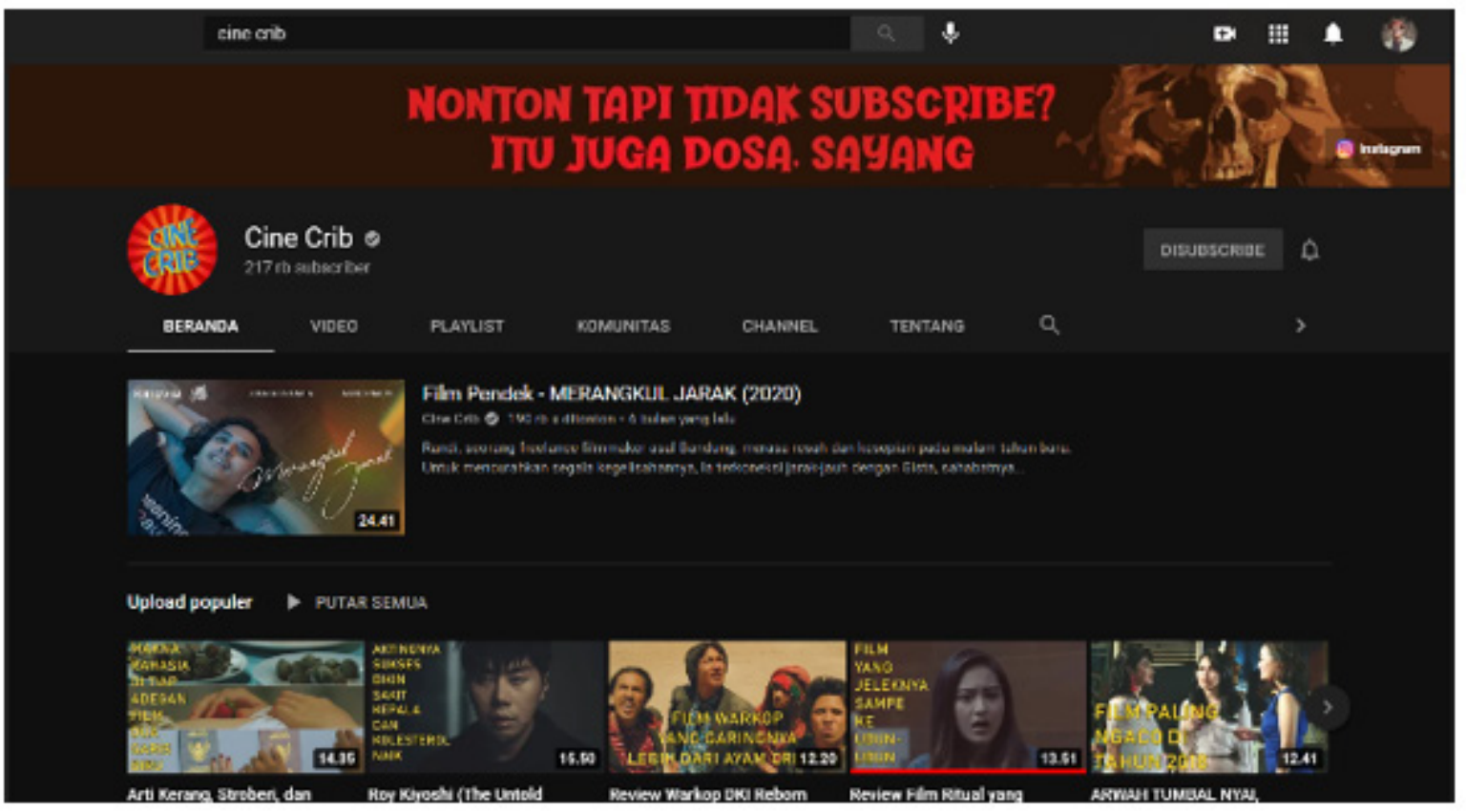

Sumber: Penelusuran YouTube Cine Crib, 2021

Gambar 1 Tampilan YouTube Cine Crib 


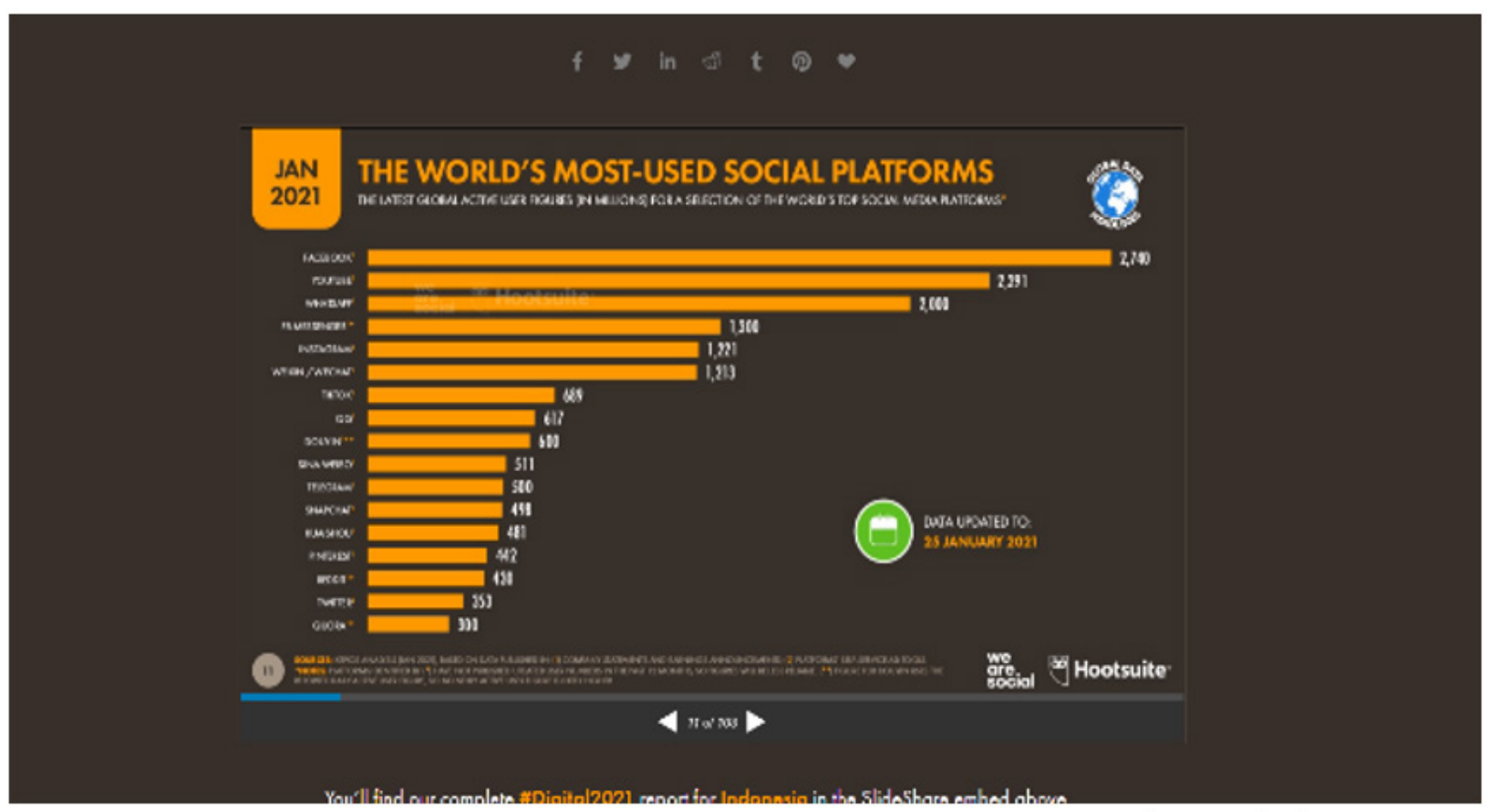

Sumber: hootsuite.com, 2021

\section{Gambar 2 Tampilan tren penguna media sosial}

subscribers adalah salah satu titik tolak sebuah channel tersebuat diminati, diperhitungkan dan hal ini selaras dengan perkembangan saat ini, salah satunya pertumbuhan internet. Merujuk pada data pengguna data internet, pada semester pertama 2021, YouTube adalah media sosial yang paling digandrungi dengan jumlah 2,291 juta pengguna di dunia, setelah Facebook (Hootsuite, 2021).

Pengguna YouTube untuk konteks Indonesia, adalah salah satu media sosial dengan durasi streaming penonton terbanyak, yakni 25,9 jam dalam satu bulan (Hootsuite, 2021). Masih dalam data hootsuite.com, YouTube juga menjadi salah satu potensi untuk menjaring iklan, dalam data lainya seperti subjek film di YouTube menjadi primadona khalayak, dan menjadi peringkat ketiga dengan banyak orang mencari (Hootsuite, 2021). Dengan kata lain, posisi Cine Crib dalam hal audience sangat potensial dan juga dalam meraup iklan cukup menjanjikan.

Maka dari itu, dengan Cine Crib membuat konten review yang menitik beratkan film Indonesia adalah keputusan yang potensial, dilihat dari kecenderungan audiens pengguna internetkhususnya YouTube di Indonesia. Dalam hal ini, pertanyaan yang sering dilontarkan pada Cine Crib adalah kenapa memilih review bukan kritik film? Satu hal yang belum banyak disadari khalayak, bahwa kritik film memiliki banyak wujud atau bentuk turunannya. Adrian Jonathan Pasaribu menganalogikan antara kritik film dan review, kritik film seperti olahraga, sedangkan 


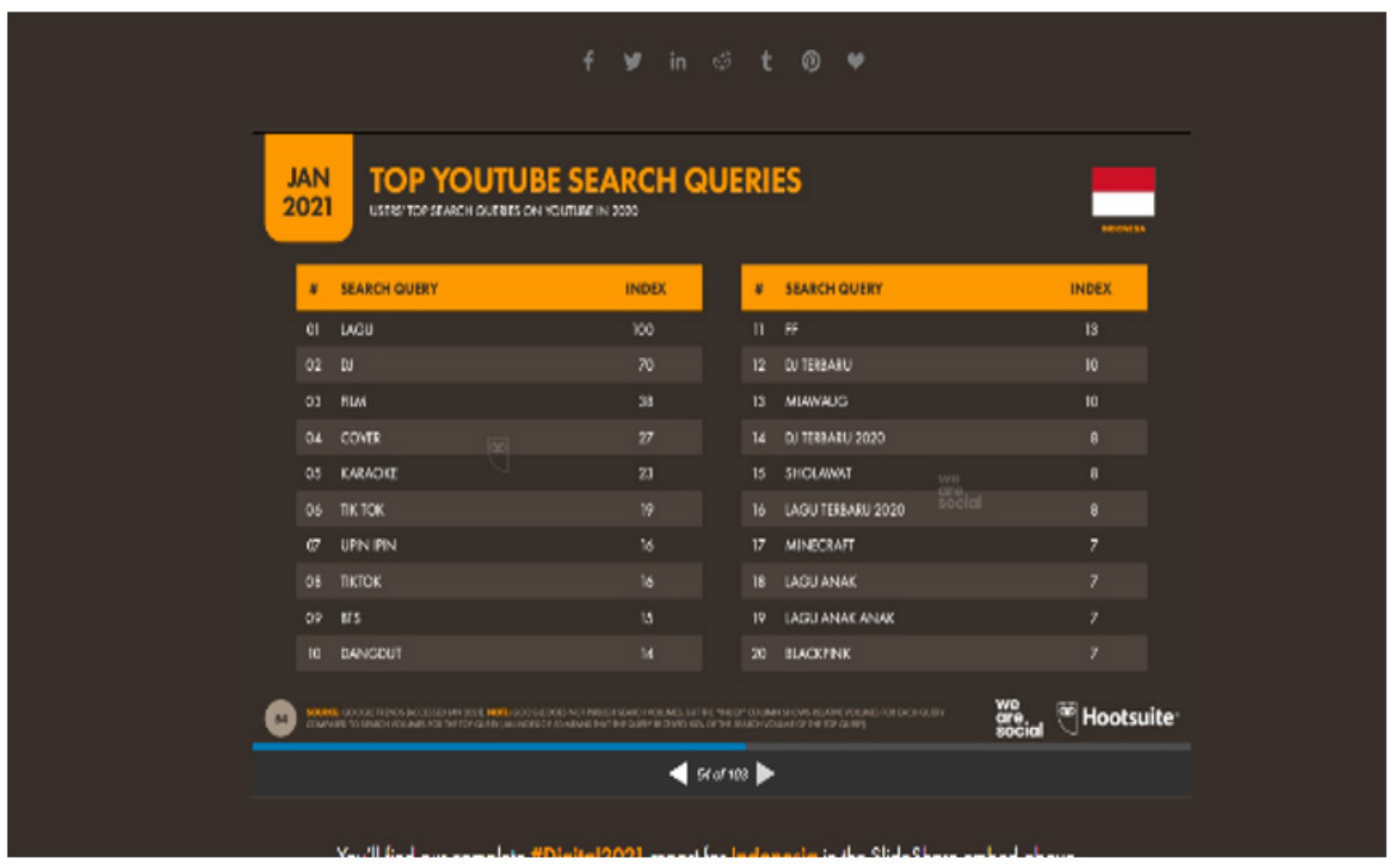

Sumber: hootsuite.com, 2021

\section{Gambar 3 Tampilan Peringkat di YouTube}

review adalah cabang olahraga (Antelope, 2021).

Pandangan khalayak terhadap konten review terkesan "remeh-temeh" atau kurang mendalam dan masih ada "dipermukaan" sedangkan essay dan kritik film lebih mendalam dan kadang bawa-bawa teori-teori yang membuat "orang awam" jelimet (Gardhadipura, 2021). Dalam hal ini, pandangan tersebut tidak ada salahnya, tetapi persoalan ke dalam itu tergantung siapa yang me-review (Gardhadipura, 2021). Ini hanya persoalan bahasa, disadur dari bahasa Inggris critic sebagai orang yang membuat tinjauan, sedangkan tinjauan yang dihasilkan disebut review (Irwansyah, 2009).

Hal lain yang perlu diluruskan adalah pemahaman soal resensi film, resensi berasal dari bahasa Belanda yang berarti recensi. Maka orang yang menulis resensi disebut resensent yang berarti maksudnya kritikus (Ningsih, 2019). Kritikus seni yang ideal, adalah kritikus yang karyanya menjadi rujukan para khalayak film, kritikus seni adalah orang yang tekun mengamati peristiwa seni, menulis serta mempublikasikannya hasil pengamatannya dengan keluasan wawasan, kedalaman dan ketajaman (Luthfi, 2017).

Menurut pengamatan penulis, bahwa komunitas Cine Crib bisa dikatakan sebagai "kritikus film", selain memiliki wawasan film yang baik, mereka juga sudah diakui oleh beberapa sineas. Seperti Salman Aristo dan 
sebagainya, Cine Crib juga diundang pada perhelatan festival film bergengsi seperti JogjaNETPAC Asian Film Festival (JAFF) 2019 dan sebagainya.

Pemilihan kata review menjadi kontekstual, atau bisa juga Cine Crib berlindung dibalik pemahaman khalayak yang masih minim. Hal ini juga yang akan ditelaah dalam tulisan ini. Dibalik itu. kesederhanaan dalam memaparkan dengan bahasa keseharian, kita juga bisa melihat kedalaman. Keseharian merupakan pengalaman langsung hari demi hari, realitas intim yang saat demi saat langsung kita jalani (Saputra, 2017).

Pengalaman Aria dalam me-review mencapai satu kesimpulan bahwa memilih pendekatan review dalam kritik film akan lebih mudah diterima khalayak, di khalayak umum kata "kritik film" memiliki konotasi yang “negatif” punya kesan mengejek dan sebagainya. Hal yang sama disadari oleh teman-teman lainnya yang tergabung di Cine Crib. Bahwa review akan lebih mudah diterima, dikarenakan khalayak umum belum terlalu paham visual literacy dalam kontek film. Maka menggunakan diksi review dirasa lebih tepat dengan kondisi khalayak saat ini (Gardhadipura, 2021).

Review menjadi pintu masuk Cine Crib untuk mensosialisasikan film Indonesia dan bagaimana cara membaca film dengan kesadaran tertentu. Cine Crib dalam setiap unggahan review menggunakan tiga pendekatan, yaitu konten, konsep dan konteks (Gardhadipura, 2021). Tiga hal tersebut diadaptasi sesuai kebutuhannya, seperti yang sering ada dalam setiap review Cine Crib adalah Sinopsis, Pros \& Cons, Spoiler dan Cinescore (Rahayu, 2020).

Pendekatan tersebut bagi penulis sudah memenuhi kriteria bagaimana mengkritik sebuah film, kritik film adalah aktivitas memecah sebuah karya (film) ke dalam penilaian atas unsur-unsurnya (cerita, penyutradaraan, akting, musik, setting, san sebagainya) sebagai suatu karya utuh dalam sebuah ungkapan penilaian (tulisan kritik) yang padu (Irwansyah, 2009).

Film selain produk komunikasi, film juga dimaknai sebagai medium seni paling lengkap. Karena film memiliki semua unsur kesenian, seperti teknik kamera, lampu, artistik, seni peran dan sebaginya. Selain itu juga, film dengan segala aktivitasnya mempu mendorong demokrasi, khusunya di Indoneia (Selechan et al., 2021).

Dalam kancah seni rupa, kritik film dibagi empat tahap dalam mengkritik sebuah karya seni; pertama deskripsi, kedua analisis formal, ketiga interpretasi dan keempat evaluasi (Feldman \& Berleant, 1975). Cine Crib memang tidak mengikuti kaidah secara formal, tetapi secara intisarinya tetap ada dalam koridor teori, yang dibawakan sesuai kebutuhan dan jaman.

Tulisan ini adalah ikhtiar penulis dalam memberikan kontribusi wacana penulisan 
film Indonesia di luar praktik produksi film. Hal ini adalah salah satu cara meretas benang kusut pemahaman apa itu kritik film, review, essay dan sebagainya. Sebagai awal, penulis akan mendudukan konteks review film yang digaungkan komunitas Cine Crib. Maka baik review, essay, kritik film dan sebagainya adalah salah satu cara bercerita dalam mengkaji film. Baik film itu sendiri dan kajian tentang film memiliki fungsi informatif dan edukatif, bahkan persuasif. Seperti halnya misi film nasional (di Indonesia) sejak 1979, bahwa selain sebagai media hiburan, film nasional dapat digunakan sebagai media pendidikan untuk membina generasi muda dalam kerangka pembangunan karakter dan bangsa (Ardianto et al., 2007).

Kenapa memilih Cine Crib sebagai subjek penelitian, penulis melihat beberapa pertimbangan. Pertama, Cine Crib memiliki penonton terbanyak di channel YouTube lainnya dengan pendekatan review film. Kedua, Cine Crib memiliki jumlah review film terbanyak, khususnya film Indonesia. Dengan mempertimbangkan hal tersebut, Cine Crib mempu mewakili kegelisahan penulis terkait tumpeng tindih pemahaman review film di Indonesia.

Satu hal lagi yang menarik dari cara Cine Crib me-review adalah interaksi Cine Crib di kolom komentar. Satu hal yang sulit dilakukan saat review film ada di media cetak dan blog sekalipun, dengan memilih YouTube sebagai medium utama me-review menjadi pembeda dengan gaya me-review sebelumnya. Disini lebih interaktif dan punya kesan dekat dengan penonton, dari pengamatan penulis ada rasa takut yang tidak bisa dipungkiri untuk masuk kedalam arena kajian film dengan me-review.

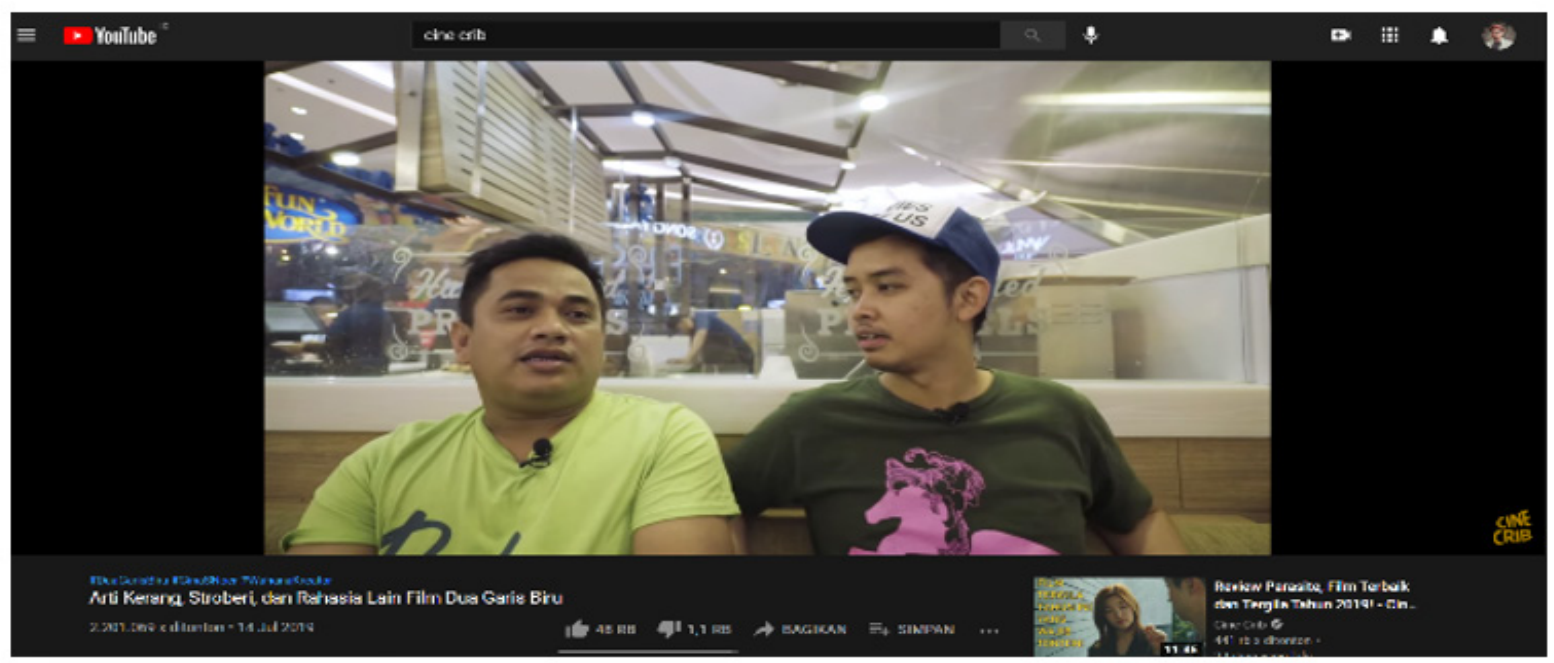

Sumber: Penelusuran YouTube Cine Crib, 2021 
Karena jelas-jelas punya peluang akan "gitugitu" saja atau punya tendensi tidak bagus. Ketakutan menjadi pengkaji film adalah kehilangan antusiasme dalam film (Pasaribu, 2011). Cine Crib memiliki konsistensi, itu juga yang menjadi pertimbangan penulis memilih Cine Crib sebagai objek penelitian ini.

Komunitas film Cine Crib menjadi gelombang baru, dalam kancah ekosistem film Indonesia sebagai penggerak dalam literasi. Dalam tradisi kritis akademik, kajian film adalah hal yang baru. Kajian film baru digaungkan oleh universitas Eropa Barat dan Amerika Serikat, pada rentan waktu pada 1960 dan 1970. Tetapi secara teori, perfilman sudah hadir hampir bersamaan dengan lahirnya film itu sendiri. Dalam konteks Indonesia kritik film lahir pada abad 20-an dengan ditandai dengan perkembangan media (Irwansyah, 2018).

Pada konteks Indonesia, yang menulis kritik film adalah wartawan, seperti yang dipaparkan Asrul Sani pada jurnal Prisma 1990, meskipun pada masa itu kritik masih seperti liputan wartawan "kritik-kritik awal tentang film lebih banyak menceritakan isi cerita film tersebut dan nama-nama pemainnya" (Irwansyah, 2018). Film sebagai media kreasi, film menjadi media penyebaran pesan. Sama halnya dengan kritik film review dan essay sebagai produk komunikasi massa. Penjelasan terkait komunikasi massa dipaparkan oleh
Bittner yaitu komunikasi massa adalah pesan yang dikomunikasikan melalui media massa kepada sejumlah besar orang (Ardianto et al., 2007).

Pada konteks kajian film di Indonesia, di mana puncaknya ada pada tahun 1970, Chairil Rachman memaparkan pada Tempo, bahwa apa yang dilakukan wartawan masa itu dalam menulis kritik film belum cukup maksimal. Pada masa itu, yang menjadi penyebabnya adalah posisi wartawan untuk meliput seni dan kebudayaan khususnya film masih dianggap sebagai sempalan dalam menulis berita, banyaknya malah mengulang ucapan sutradara dan produser (Irwansyah, 2018). Dalam konteks media massa, rasanya sampai hari ini masih relevan. Rubrik seni dalam media massa masih dilihat sebagai rubrik pelengkap, dan tidak didudukan pada konteks yang komprehensif.

Hal tersebut memberikan kesan tidak berbobot pada review film, kondisi kritik film saat ini dalam media massa masih tidak ada bedanya dengan 1970. Maka dari itu, semangat Cine Crib lahir untuk mengisi kekosongan media massa, yang menggarap bahwa menulis review atau ulasan film bukan hal yang penting dan serius. Padahal menulis review film adalah salah satu dalam praktik kajian film.

Mendudukkan review film Cine Crib adalah dengan cara untuk menelaah bagaimana proses me-review film dengan pendekatan metodologi 
dan epistemologi, sehingga kajian film dalam konteks ini review bisa diterima sebagai produk intelektual. Tulisan ini akan membahas bagaimana proses Cine Crib me-review film, khususnya film Indonesia. Cara pandangnya dalam membedah proses Cine Crib me-review meminjam Richard Dyer dalam buku Oxford Guide to Film Studies yang mempopulerkan dua pendekatan dan tiga hal yang perlu dipelajari dalam mengkaji film: teori film, kritisisme film dan sejarah film. Dyer memaparkan dua dua pendekatan teori yakni formal-estetik dan wacana kritik (Ernesto, 2011).

Bagi penulis, yang menarik dari proses Cine Crib me-review film adalah bagaimana para reviewer tersebut memposisikan sebagai penonton "yang beriman". Penulis sebagai penonton review Cine Crib, merasa pada setiap mereka me-review film, reviewer-nya menempatkan cara berfikirnya seperti penonton pada umumnya, disampaikan dengan bahasa keseharian dan tidak njelimet, namun tetap memerhatikan aspek metodologisnya. Seperti yang dijelaskan Dyer bahwa wacana psikologis penonton yang memahami, menyimpulkan dan berkreasi sebagai sensasi menonton film melalui laman YouTube-nya (Ernesto, 2011).

Maka berdasarkan latar belakang yang telah dipaparkan di atas, penelitian ini difokuskan pada proses komunitas film Cine Crib dalam me-review film Indonesia. Bagaimana proses
Cine Crib me-review dengan beberapa tahapan, pertama bagaimana menentukan tema film yang di-review, kedua bagaimana menentukan tugas setiap anggota untuk me-review. Ketiga, kaidah apa yang dipakai untuk me-review film dan terakhir, atau keempat bagaimana proses kurasi atau editing dari apa yang akan ditampilkan di laman YouTube Cine Crib.

Empat tahapan bagaimana Cine Crib mereview film tersebut menjadi kunci dalam penelitian ini, yang kemudian penulis bedah mengunakan Teori Manajemen dari George R Terry. Teori tersebut penulis yakini sebagai cara bagaimana mengurai aktivitas yang dilakukan Cine Crib, sebagai komunitas dalam mereview film. Teori manajemen ini digunakan dengan alasan bahwa sebuh organisasi apapun bisa ditelaah dengan lintas keilmuan, ini adalah upaya dalam bentuk mengorkestrasi komunitas. dimana tori tersebut terdiri dari empat cara: Planning, Organizing, Actuating dan Controlling (POAC) (Terry, 2012).

Sebagai teori generik manajemen, POAC yang kemudian dicangkokkan dalam tulisan ini. Penulis sadari betul, hal ini dilakukan untuk berangkat dari hal yang sangat mendasar dalam pengelolaan organisasi. Kemudian, selain dilihat dari aspek teoretis, penulis menggunakan metode deskriptif kualitatif, tujuannya untuk menguraikan aspek review film dari model penelitian yang paling dasar. Harapannya, 
penelitian ini bisa memberikan pintu masuk yang terstruktur dalam kajian film, dilihat dari berbagai aspek teoretis dan metodologis.

\section{METODE PENELITIAN}

Pada penelitian ini, penulis menggunakan metodologi kualitatif. Pertimbangan dalam menentukan metodologi penelitian ditentukan oleh perspektif teoretis yang penulis gunakan, dalam penelitian ini penulis melakukan pandangan teoretis terhadap isu yang diangkat.

Metode ini penulis gunakan untuk memahami fenomena tentang apa yang dialami, oleh subjek penelitian. Misalnya perilaku, persepsi, motivasi, tindakan dan lainnya. Secara holistik dan dengan deskripsi dalam bentuk kata-kata dan bahasa pada suatu konteks yang alamiah, dan memanfaatkan berbagai metode alamiah (Moleong, 2017).

Maka dengan ini, memungkinkan penulis memahami data dan menghubungkan data yang rumit dengan peristiwa dan situasi lainnya (Mulyana, 2018). Selanjutnya, Mulyana menurunkan dalam dua kategori penelitian, kualitatif dan kuantitatif. Kualitatif dipilih karena didasarkan pada upaya membangun pandangan terhadap apa yang diteliti dengan rinsi, melalui kata-kata, gambaran, holistik dan rumit (Moleong, 2017).

Penelitian ini menggunakan dengan pendekatan deskriptif - kualitatif sebagai teknik atau prosedur, untuk membedah alur pemikiran umum, dan gagasan teori yang penulis gunakan. Metode deskriptif menekankan pada pengetahuan yang mendalam dan pada penyempurnaan serta elaborasi gambar yang sesuai untuk penelitian sosial (Ragin \& Amoroso, 2011).

Pada hakekatnya, metode deskriptif mengumpulkan data secara univariat. Karakteristik data diperoleh dengan ukuranukuran kecenderungan pusat atau ukuran sebaran (Rakhmat \& Ibrahim, 2017).

Lebih jauh dari itu, yang dipaparkan di atas ada empat metode deskriptif, pertama mengumpulkan informasi aktual secara rinci yang melukiskan gejala yang ada. Kedua, mengidentifikasi masalah atau memeriksa kondisi dan praktik-praktik yang berlaku. ketiga, membuat perbandingan evaluasi. Empat, menentukan apa yang dilakukan orang lain dalam menghadapi masalah yang sama dan belajar dari pengalaman mereka untuk menempatkan rencana dan keputusan pada waktu yang akan datang (Rakhmat \& Ibrahim, 2017)

Melihat empat poin diatas, ada dua hal juga yang perlu digaris bawahi dalam penelitian menggunakan metodologi deskriptif yaitu; pertama penulis harus memiliki sifat reseptif; selalu mencari tahu bukan menguji. Kedua, penulis harus memiliki kekuatan integratif; 
kekuatan untuk memadukan beragam informasi yang diterima menjadi satu kesatuan. Maka dengan kualifikasi diatas, peneliti deskriptif bukan saja menjabarkan (analisis), tetapi juga memadukan (sintesis). Bukan saja melakukan klasifikasi, tetapi juga organisasi, dan dari metode penelitian ini nantinya dikembangkan berbagai penelitian korelasional dan eksperimental (Rakhmat \& Ibrahim, 2017).

Sederhananya, penulis akan memotret atau menggambarkan kembali realitas yang terjadi pada proses komunitas film Cine Crib dalam me-review film, khusunya film Indonesia. Selain itu, metode ini bisa menjadi pembuka atau jalan bagi penelitian selanjutnya dalam konteks kajian film, khususnya review film.

\section{HASIL DAN PEMBAHASAN}

Bermula dari ketertarikan personal atas film dan menulisnya di blog, Aria Gardhadipura biasa dipanggil Aria mencatatnya dengan tanpa tujuan apapun, Aria hanya percaya atas hasratnya tentang film, baik dalam menonton atau menulis. Apa yang menjadi ketertarikan dalam film tersebut, Minat menulis Aria hadir Jauh sebelum menulis di blog, Aria semasa kuliah di Fakultas Hukum Universitas Padjadjaran sudah tertarik di dunia film, dan pernah terlibat dalam film pendek dan produksiproduksi lainya dalam khasanah perfilman.

Hasrat menulis film terasa cukup deras di saat Aria sedang "buntu" dalam menulis skripsi, maka dikala menulis skripsi mengalami

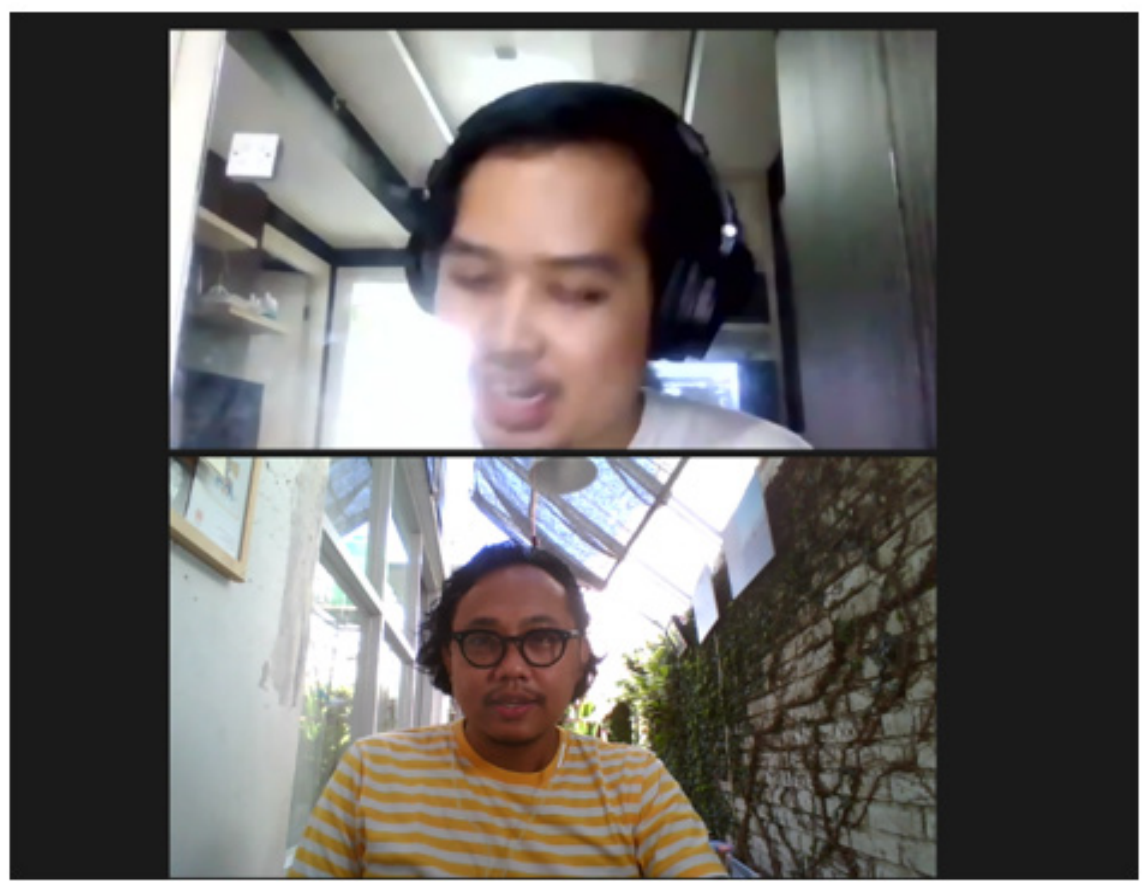

Sumber: Penelusuran YouTube Cine Crib, 2021

Gambar 5 Wawancara penulis dengan narasumber 
kejenuhan, Aria berpaling pada aktivitas yang dirasanya menyenangkan, yaitu nonton film dan menulis review film. Pada masa-masa itu Aria cukup aktif menulis, dan mencapai puncaknya saat Aria sudah bekerja di media online di Jakarta. Saat itu mungkin pada kisaran 2010 atau 2011, dikarenakan sudah punya penghasilan dan lebih leluasa menonton film apapun (Gardhadipura, 2021).

Selain menulis di blog, Aria juga aktif di beberapa forum seperti Kaskus, pada masa itu, forum seperti Kaskus cukup populer untuk berjejaring. Pada kesempatan tersebut, yang Aria lakukan juga selain berjejaring adalah belajar dan melihat cara pandang penulis film lainnya dalam menulis gagasan tentang film.

Sampai pada 2015 blog Aria terkena virus malware, yang mengakibatkan seluruh tulisannya hilang. Dengan momen tersebut, Aria merasa tidak bersemangat lagi untuk menulis review film. Selang satu tahun tepatnya 8 Desember 2016, Aria dan kawannya Adriano Rudiman menggagas channel YouTube dengan nama Cine Crib.

Adriano yang memiliki ide atas nama tersebut, terinspirasi dari acara televisi 90an di channel MTV yang bernama MTV Cribs, semangat acara tersebut yang coba akan diadaptasi oleh Cine Crib sebagai identitas tayangannya. dimana saat itu, review film dipandang serius dan njelimet. Cine Crib ingin dikenal dengan channel yang santai dan hangat dalam me-review film, ngobrol dan mengalir apa adanya.

Film yang pertama kali di-review adalah Headshot, besutan dua sutradara Timo Tjahjanto dan Kimo Stamboel yang tergabung dalam The Mo Brothers. Review tersebut sudah ditonton 5.536 kali (Crib, 2021). Pada tayangan pertama tersebut, salah satu host nya berujar, kalau Cine Crib adalah channel yang akan menitik beratkan pada review film Indonesia. Beruntungnya sampai saat ini masih konsisten me-review film Indonesia, dengan jumlah film Indonesia yang masih tidak sebanding dengan film Hollywood, secara jumlah Cine Crib sangat berdedikasi untuk hal ini.

Seriring berjalannya waktu, Cine Crib pada saat ini sudah merambah ke berbagai program lain. Tetapi programnya masih dirasa sejalan dengan visi Cine Crib sebagai sebuah komunitas film. Program tersebut seperti web series, berkolaborasi dengan komunitas lainnya dengan membuat film pendek, membuat channel baru seperti 5 Menit Bersama LARA CROT \#VLOG dan sebagainya. Sampai saat ini Cine Crib menjadi salah satu channel dengan jumlah subscriber terbesar untuk kategori channel review film.

Format konten saat ini, tidak terlepas dari inspirasi berbagai channel. Dalam membuat konten, Cine Crib pada awalnya secara tampilan 
visual dan isu mengkombinasikan antara channel Screen Junkie dan ScreensaverID, dua channel tersebut yang menjadi referensi dalam merumuskan identitas Cine Crib saat itu (Gardhadipura, 2021). Hal tersebut dipandang sebagai dasar atau pondasi, meskipun akhirnya Cine Crib saat ini muncul dengan personality setiap reviews atau member-nya.

Secara format penyampaian, review film Cine Crib dikemas dengan sangat personal, apa adanya tetapi masih dalam koridor kajian film. Cine Crib menyadari bahwa review adalah produk dari media komunikasi massa, karena sebuah film mempu memengaruhi sikap, perilaku dan harapan bagi orang-orang di seluruh dunia (Permana et al., 2019).

Sama halnya dengan kajian film, dalam format review. Maka ada baiknya, cara dalam menyampaikan gagasan adalah dengan apa yang sekiranya dipahami oleh khalayak umum. Hal tersebut terbukti apa yang dilakukan Cine Crib, menjadi rujukan penonton Indonesia yang ingin mendengarkan review film terkini, khususnya film Indonesia.

Maka dengan pertimbangan tersebut, mereview film Indonesia menjadi salah satu usaha Cine Crib memberikan pandangan populer agar film Indonesia semakin maju. Hal ini harus disadari karena kajian film itu sendiri adalah elemen media komunikasi masa, yang akan mempengaruhi banyak tingkatan masyarakat. Salah satu fungsi komunikasi massa adalah mentransmisikan budaya, maka budaya tersebut perlu ada perhatian khusus (Permana et al., 2019)

Secara proses dalam me-review film, seperti yang sudah dipaparkan di atas, bahwa Cine Crib adalah komunitas film yang dimana semua keputusan komunitas tersebut mempertimbangkan kesepakatan bersama. Sebagai komunitas yang cukup "cair" tetapi selektif, berjalannya dengan waktu Cine Crib menyadari bahwa dalam sebuah komunitas harus ada yang menjadi pemimpin. Tujuannya untuk memutuskan dan memberi kebijakan, arahan dan sebagainya, agar komunitas Cine Crib ini masih dalam visi yang sama.

Seperti dalam hal menetukan tema film yang akan di-review, Cine Crib sebagai komunitas sepakat tidak ada teman spesifik. Dimana tidak mengharuskan film tertentu atau genre tertentu, yang menjadi kewajiban dalam me-review. Namun demikian, Cine Crib lebih menitikberatkan film Indonesia, seperti visi pertama kali Cine Crib digagas. Tujuannya agar khazanah film Indonesia semakin kaya, dan juga untuk mengangkat dan memperkenalkan film Indonesia lebih luas lagi, dengan menitikberatkan review film.

Cine Crib harus menjalani proses yang tidak mudah untuk mencapai titik ini. Dari pengamatan penulis, Cine Crib melaluinya 
dengan kerja keras dan tetap konsisten terhadap apa yang mereka percaya. Ditambah pandangan khalayak terhadap review film yang tidak semuanya memndang positif (Macdowell \& Mcculloch, 2019). Komunitas film Cine Crib membebaskan film apa pun yang mau di review, tidak ada penugasan khusus, semua berangkat dari ketertarikan personal.

Channel YouTube Cine Crib tidak hanya berisi review film, tetapi terdapat kategorisasi lain dalam menu atau rubrik, yang popular disebut playlist. disana terdapat beberapa playlist seperti review film Hollywood/Foreign, edisi special, review film Indonesia, review film horor Indonesia, rekomendasi film bulanan, review Aria sendirian dan sebagainya. Hal ini memberikan kesan bahwa ada penunjukan atau spesialisasi, dalam pengkategorian khususnya dalam menentukan tema. Menurut Aria Hal tersebut dibutuhkan untuk memudahkan penonton dalam mencari video yang diinginkan dalam channel YouTube Cine Crib (Gardhadipura, 2021).

Pada dasarnya Cine Crib tidak ada batasan tema film yang akan di-review, karena sebenarnya, kesepakatan yang disetujui oleh semua anggota Cine Crib adalah me-review film sesuai ketertarikan anggotanya. Tema lahir dari anggotanya itu sendiri, Cine Crib membebaskan film apa saja yang akan di-review.

Setiap anggotanya memiliki karakteristik atau memiliki ketertarikan personal terhadap

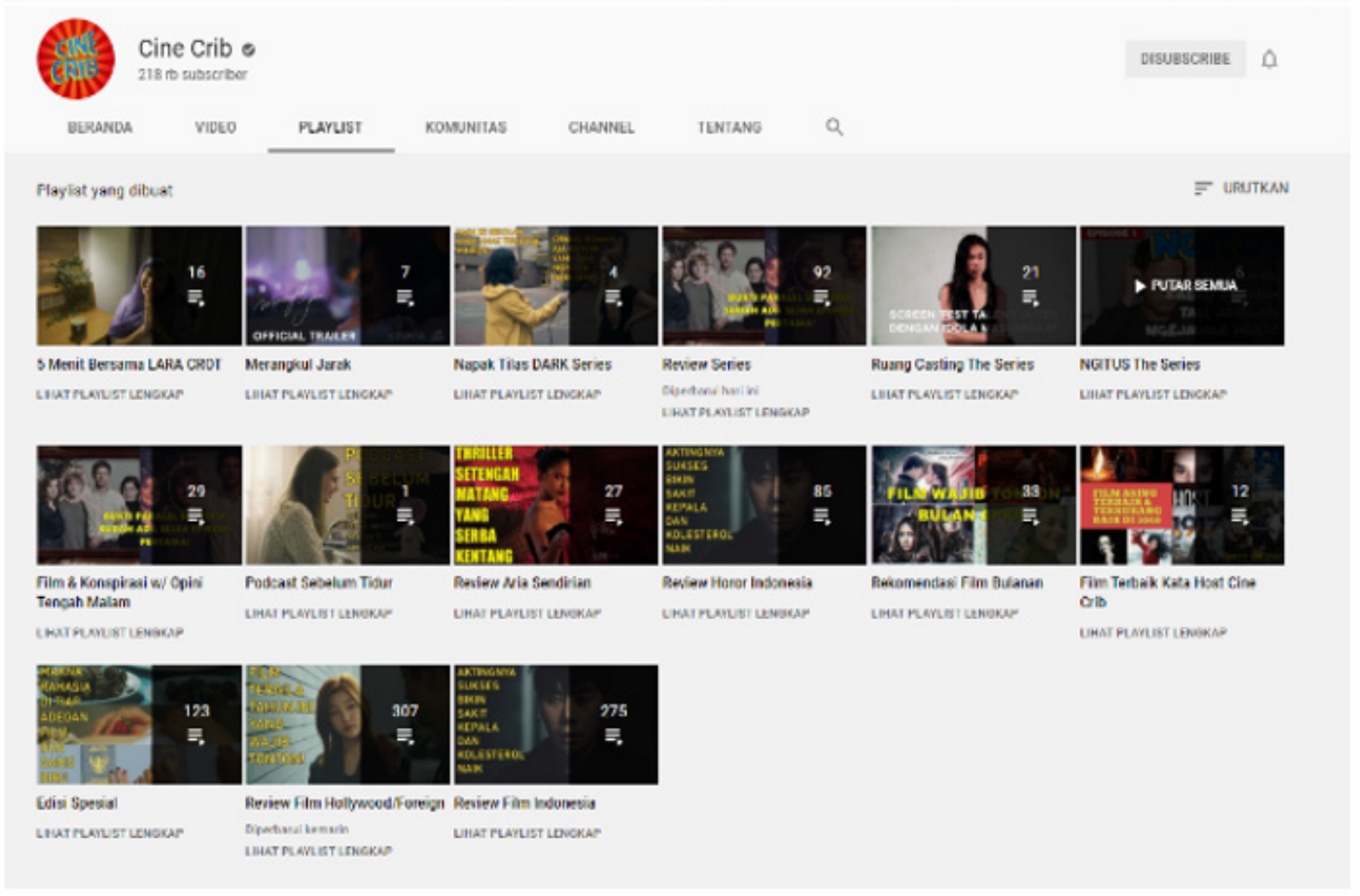

Sumber: Penelusuran YouTube Cine Crib, 2021

Gambar 6 Playlist dalam YouTube Cine Crib 
kategori film tertentu, seperti halnya ada yang tertarik hanya me-review film hantu, seri dan sebagainya. Meskipun Aria mendorong sesama anggota yang lainnya untuk mereview berbagai macam aliran film, atau keluar dari zona nyaman yang hanya tertarik dalam kategori film-film itu-itu saja.

Seperti halnya Aria, karena dorongan untuk menonton film cukup besar, jadi Aria memiliki kecenderungan untuk menonton banyak film dari berbagai macam aliran film. Hal tersebut membuat Aria memiliki khasanah film yang luas, karena menonton dari berbagai aliran dan tidak berhenti dalam satu kategori.

Dengan menonton film dari berbagai aliran, maka dalam kontek Cine Crib hal tersebut cukup membantu, kalau ternyata dalam satu minggu sesama anggota tidak ada yang mengirimkan review filmnya. Maka dengan kondisi tersebut Aria berinisiatif untuk me-review film apapun, salah satunya untuk memenuhi kuota dalam satu minggu harus mengunggah satu vedio review. Sampai di playlist Cine Crib ada rubrik khusus "review Aria Sendirian". Hal ini dilakukan, untuk memenuhi komitmen Cine Crib sebagai komunitas, yang akan mengunggah hasil review film setiap minggu ke YouTube.

Lebih lajut, selain menentukan tema. Proses berikutnya adalah bagaimana menentukan yang siapa me-review di channel Cine Crib, sejauh ini tidak banyak perbedaan seperti bagaimana menentukan tema yang akan di review (Gardhadipura, 2021). Secara formal tidak ada penunjukan secara khusus, tetapi mungkin pada awalnya Aria masih mendorong sesama anggota untuk inisiatif membuat review.

Pada prosesnya menentukan reviewer tidak mudah, perlu banyak inisiatif dari Aria atau anggota lainya untuk tetap konsisten setiap minggunya membuat review film. Cine Crib mendorong inisiatif dan konsistensi dari setiap anggotanya untuk terus aktif dalam mereview, meskipun kadang kala Aria membuat review untuk stok, seperti yang dipaparkan sebelumnya.

Maka secara formal, baik tema dan personal yang me-review, Cine Crib tidak ada klausul formal. Cine Crib lebih mengedepankan kesadaran individu. Aria percaya yang bergabung dengan Cine Crib karena atas dasar kesamaan visi dan kecintaan terhadap film , khususnya dalam me-review film Indonesia.

Kaidah teoretis yang digunakan dalam proses review film dalam komunitas Cine Crib berangkat dari kaidah yang umumnya dalam me-review film. Secara teoritis tidak ada aspek yang dirujuk, hanya lebih mengedepankan pengalaman menulis dan membaca bagaimana orang lain me-review film. tetapi memang Cine Crib menyepakati tiga aspek yang secara ideal harus terpenuhi dalam me-review film, yaitu konten, konsep dan konteks (Gardhadipura, 
2021).

Tiga aspek kesepakatan tersebut, dikebangkan atau disesuaikan dengan kebutuhan dan visi Cine Crib. kembali pada visi Cine Crib dalam me-review adalah untuk memberi khasanah referensi film, dengan lebih santai sekaligus menghibur; di mana tiga aspek tersebut dimodifikasi agar bisa diterima oleh berbagai kalangan.

Pakem yang digunakan dalam me-review film gaya Cine Crib adalah Sinopsis, Pros \& Cons, Spoiler dan Cinescore, tetapi aspek-aspek tersebut tidak baku dan kaku atau mewajibkan harus seperti aspek teori tersebut. Cine Crib memberikan kelonggaran dalam teknis mereview film. Ini hanya panduan yang ideal gaya Cine Crib. Pertanyaannya, kenapa tidak dibakukan, Aria berujar hal tersebut kami sadari bahwa banyak aspek yang tidak perlu sekaku media massa. Sebagai contoh ada film yang tidak membutuhkan semua tahapan seperti Sinopsis, Pros \& Cons, Spoiler dan Cinescore tetapi cukup mengedepankan sinopsis dan Cinescorem maka bagi Cine Crib hal tersebut tidak mengapa. Selama pembahanya masih ada dalam koridor dan visi Cine Crib.

Seperti yang penulis kutip dari media daring IDN Time, Rasid salah satu anggota Cine Crib memaparkan lima hal yang harus dimiliki oleh seorang reviewer dalam me-review film. Pertama adalah konten, hal ini penting untuk menguliti konteks apa yang ingin disampaikan oleh pembuat film tersebut dilihat dari aspek adegan dan properti yang dipilih oleh pembuat film persebut. Kedua adalah konsep, hal ini berkaitan dengan aspek konten, apa yang terbarukan dari yang menjadi kekhasan film tersebut dilihat dari teori dan logika si pembuat film tersebut apakah sudah sesuai atau belum dengan tujuan yang ingin dicapai oleh sutradara tersebut. Ketiga adalah konteks, pada bagian ini erat hubungannya dengan aspek budaya, politik, gaya hidup dan sebagainya. Keempat sinematografi, aspek ini meliputi pembacaan gambar atau visual, apakah gaya visual tersebut cukup sesuai dengan konten, konsep dan konteks cerita. Terakhir bagian kelima adalah ketertarikan secara khusus, misalnya dalam film tersebut yang me-review menyoroti isu gender, lingkungan, kesehatan mental dan sebagainya (Insani, 2020).

Maka dilihat dari hal tersebut, poin yang digunakan oleh anggota Cine Crib sangat "cair", sesuai dengan kepribadian dan pengetahuan anggota Cine Crib. Dalam me-review Cine Crib memberikan ruang interpretasi yang cukup luas dan subjektif, karena Cine Crib menyadari bahwa subjektifitas tersebut, menyesuaikan dengan vocabulary visual atau hal yang terkait studi film yang dikuasai oleh yang me-review. Hal yang disadari juga bahwa penonton juga memiliki unsur subjektivitas, seperti dalam 
menilai sebuah film.

Seperti yang sudah dipaparkan sebelumnya, Aria memegang peranan penting dalam komunitas film Cine Crib. konteks ini dimaksudkan untuk menjaga "marwah" Cine Crib itu sendiri seperti apa yang disepakati bersama dengan anggota kelompok lainnya. Aria posisinya bukan dalam artian ketua, tetapi lebih seperti "kurator" dalam menyeleksi konten yang tayang di channel YouTube Cine Crib khususnya untuk review film.

Hal ini dilakukan karena Cine Crib memiliki konten lain, seperti terlibat dalam produksi film pendek, YouTube series dan Lara Crot. Konten di luar review dikerjakan oleh tim dengan kesepakatan supervisi anggota Cine Crib yang lain. Secara teknis anggota Cine Crib me-review film secara mandiri, lalu materi mentahan videonya dikirim ke Aria.

Dengan minat khalayak terhadap konten Cine Crib begitu antusias, menjadi tantangan sendiri bagi Cine Crib dalam editing video. Hal ini yang selalu menjadi bahan diskusi sesama anggota Cine Crib. Cine Crib mulai menggagas untuk memulai editing oleh orang ketiga, karena selama ini yang mengerjakan hampir keseluruhan editing review film adalah Aria. Harapanya orang ketiga tersebut bisa mengedit video, di mana Aria dan anggotanya hanya cukup supervisi.

Cine Crib sudah mencoba opsi tersebut, tetapi masih dirasa kurang pas dari segi durasi, pemotongan konteks konten review dan hal-hal mana saja yang perlu ditekankan. Karena pola "teoretis" review film gaya Cine Crib cukup "cair", maka sulit menemukan batas formal atau batasan yang jelas dalam me-review film dengan gaya Cine Crib. Maka dengan argumen tersebut, masih cukup sulit proses editing ini dilimpahkan kepada pihak ketiga, dikarenakan editor video bukan sekedar menguasai teknik editing tetapi harus memahami unsur visi yang dimiliki Cine Crib.

Pada proses editing, Aria bukan hanya sekedar "menjahit" video review dan menentukan durasi, tetapi juga terlibat dalam menentukan judul video yang akan diunggah ke channel YouTube Cine Crib. Hal tersebut. Dilakukan berdasarkan kesepakatan bersama, apakah hasilnya sudah sesuai yang diharapkan atau belum.

Film sebagai produk kebudayaan sama halnya dengan review dan kritik film. Bagaimana proses Cine Crib me-review film khususnya film Indonesia adalah suatu proses memperkuat ideologi yang diusung film sebagai sebuah medium. Ideologi dapat dipahami sebagai suatu sistem tentang penjelasan akan eksistensi suatu kelompok sosial, dan atau individu sebagai upaya adanya merasionalisasikan hubungan kekuasaan antara kelompok atau kelas-kelas sosial di dalamnya (Wahid \& Agustina, 2021). 
Dengan film diyakini sebagai produk komunikasi massa, sama halnya dengan produk turunanya seperti kritik film dan dalam konteks artikel ini adalah review film. Review film memiliki kekuatan dimana salah satu fungsinya adalah menyampaikan secara luas kepada masyarakat yang dikemas dengan popular, baik dalam tulisan maupun storytelling video. Seperti yang dilakukan Cine Crib, video storytelling dengan memanfaatkan media sosial YouTube.

Pada umumnya review film disampaikan melalui medium media massa, dengan metode yang beragam sesuai kebutuhan dan ideologi media tersebut. Sedangkan kritik film hadir pada ulasan-ulasan terbatas bukan rubrik khusus dalam media massa dan umumnya sering ada di jurnal yang membahas fenomena film secara luas.

Review dan kritik film sering dimaknai oleh khalayak umum sebagai "hujatan" apalagi yang terlibat dalam film tersebut, selalu dimaknai dengan ketersinggung. Baik Dalam review atau kritik film. Salah satu anggota Cine Crib Razak Syarif, pernah mengalami ancaman dari salah satu rumah produksi melalui pesan pribadi di akun Instagramnya pada 1 Desember 2019. Ancaman tersebut berisi rasa keberatan karena Razak Syarif dinilai merugikan rumah produksi tersebut. Bahkan, Razak Syarif diancam dilaporkan kepolisian (Alaidrus, 2020). Padahal apa yang disampaikan Razak Syarif selalu mengibur dan humor, setidaknya dari pengamatan personal penulis. Humor dalam tradisi literasi serung digunakan sebagai cara untuk menyampaikan kritik (Purwoko, 2021).

Melihat realitas tersebut, secara fungsi atau gunanya, review film dibagi menjadi tiga bagian. Pertama, mendapatkan sudut pandang lain ketika memaknai sebuah film. Kedua, menemukan relevansi antara sinema dengan kehidupan. Ketiga adalah menambah referensi dan pengetahuan seputar film. Sedangkan gunanya untuk pembuat film atau yang bergelut di industri film dibagi tiga. Pertama, mendapatkan sudut pandang lain yang mungkin tidak terpikirkan sebelumnya. Kedua, secara tidak langsung menjadi sarana untuk memperkenalkan karya kepada publik. Ketiga, adalah menjadi catatan rekam jejak filmmaker yang dapat dikaji kembali di kemudian hari (Antelope, 2021).

Di bagian pendahuluan, penulis menggarisbawahi bahwa review adalah produk turunan dari kritik film, dalam pemahaman lain, kritik film adalah analisis ilmiah dan mendalam tentang f ilm yang biasanya diterbitkan dalam artikel dan buku akademis bertahun-tahun kemudian. Kritik dapat berfokus pada satu film, genre film, karya sutradara atau aktor, dan banyak lagi. Hal ini sering dibingkai melalui lensa teori film (Knapp, 2013). Sedangkan review film dimaknai sebagai produk yang 
populer, biasanya diterbitkan di media massa seperti majalah, surat kabar cetak atau juga online seiring pada hari rilis film tersebut. Dalam me-review ada beberapa poin yang perlu hadir seperti memberikan sinopsis, plot dan sering kali peringkat atau rekomendasi (Flinn Sr, 1941).

Apabila merujuk pada aktivitas komunitas film Cine Crib, dilihat dari proses bagaimana Cine Crib me-review film dengan empat proses tahapan. Pertama, bagaimana Cine Crib menentukan tema; kedua, menentukan siapa yang me-review; ketiga, menentukan aspek teori dan terakhir keempat, bagaimana proses editing. Hal ini meyakinkan penulis bahwa setiap tahapnya sudah melalui perencanaan yang matang dan yang pasti selalu adaptif. YouTube yang digunakan Cine Crib sebagai medium baru dalam menyebarkan informasi, selayaknya sebuah media tidak terkecuali film yang termasuk dalam strujtur kebudayaan (Hakim, 2021).

Sebagaimana penulis juga singgung di latar belakang, pada bagian ini penulis akan membahas empat fungsi manajemen (POAC) yang diungkapkan George R Terry. Teori ini digunakan untuk menelaah bagaimana Cine Crib berproses sebagai komunitas film, teori ini lazim digunakan dalam sebuah perusaaan yang profitable. Alasan penulis mencangko dari tradisi manajemen untuk sebuah organisasi atau kelompok literasi budaya, dikarenakan argumen Terry dalam prinsip manajemen mengungkapkan bahwa, sebuah usaha bersama untuk mencapai tujuan yang sudah ditetapkan bersama satu tim (Terry, 2012). Maka tidak ada prasyarat bahwa teori ini hanya berlaku untuk sebuah organisasi profitable.

Apa yang sudah dilakukan oleh Cine Crib sebagai komunitas film saat ini, memenuhi parasyarat bahwa untuk sebuah komunitas memiliki keinginan untuk menjadi besar, maka dibutuhkan sistemn mamajemen yang baik. Hal ini memperlihatkan bahwa teori POAC George R. Terry cukup tepat dalam membedah Cine Crib berproses sebagai sebuah komunitas film yang bergerak dalam literasi film.

Bagian pertama dalam teori Terry adalah Planning atau Perencanaan, Perencanaan adalah serangkaian kegiatan dalam memutuskan berbagai kegiatan yang dimulai dari apa yang harus dilakukan, kapan, bagaimana dan oleh siapa (Terry, 2012). Sebagai catatan Terry menekankan "objectives" sebagai titik awal atau tujuan-tujuan organisasi. sebagaimana yang sudah Aria paparkan diatas, bahwa Cine Crib adalah organisasi yang dimana isinya adalah orang-orang satu visi untuk memberikan wacana perfilman di Indonesia, dengan cara yang santai dan bisa diterima oleh khalayak banyak. pada titik objectives Cine Crib sampai saat ini masih menjalankan sesuai visinya dari 
awal berdiri, yakni menyampaikan review film dengan hangat ke pemirsa film Indonesia.

Bagian kedua adalah fungsi Organizing atau pengorganisasian. Pada bagian ini cukup menantang, dikarenakan yang menjadi magnet dalam komunitas ini hanya komitmen personal terhadap dunia film. Aria sebagai founder Cine Crib mengajak kawan-kawan yang sevisi untuk mewujudkan cita-cita Cine Crib sebagai platform dalam me-review film.

Cine Crib dibagun dari visi yang sama atas ketertarikan terhadap film dan khasnya film Indonesia. Penelusuran penulis mengenai hal ini adalah, bagaimana pengorganisasian Cine Crib tidak terlalu "ketat" dan "rigid", tetapi membawa kenyamanan dalam berkomunikasi tanpa rasa ada tekanan pekerjaan dalam sebuah komunitas Cine Crib, karena semua anggotanya bekerja atau menghasilkan uang ditempat lain, dengan beragam disiplin ilmu dan tidak terpaku pada dunia film, sebagai penghasilan utama. Itu juga yang mungkin dari pengamatan penulis Cine Crib cukup solid, sampai saat ini sebagai komunitas, karena Cine Crib menjadi tempat berkumpul melepas penat pekerjaan lainya.

Ketiga adalah menerapkan fungsi Actuating atau penggerakan, fungsi penggerakan sendiri ialah tujuan individu dalam kelompok (Terry, 2012). Aria sebagai founder Cine Crib menjadi orang yang mengorkestrasi komunitas, tetapi masih berlandaskan kesepakatan bersama. semua anggota memiliki suara yang sama dalam mengekspresikan idenya, selama masih dalam visi Cine Crib.

Bagian keempat adalah penerapan fungsi Controlling atau pengawasan. Pada dasarnya semua anggota Cine Crib memiliki suara yang setara satu sama lainya, seperti halnya dalam hal pengawasan komunitas. tetapi ada hal yang menitik beratkan pada editing, yakni Aria sendiri yang mengedit hampir semua video yang tampil di channel YouTube Cine Crib. hal ini dilakukan untuk menjaga kualitas isi dari review tersebut, Aria dalam hal ini sebagai "kurator" dari review film oleh Cine Crib.

Dari empat poin tersebut terlihat jelas sudah sejalan dengan visinya. Dalam hal ini, Cine Crib adalah komunitas film yang fokus dengan me-review film dengan platform media sosial YouTube sebagai medium untuk menyebarluaskan konten mereka dengan cara yang lebih bisa diterima khalayak luas, tujuannya agar film Indonesia mendapatkan kekayaan cara pandang, karena film adalah salah satu medium untuk mentransmisikan budaya dan memperkenalkan Indonesia di kancah internasional (Permana et al., 2019).

Penelitian ini juga melihat bahwa relasi antara medium yaitu media massa dalam konteks ini media sosial YouTube memberikan peranan penting. Tujuanya untuk memasyarakatkan relasi yang dikontruksi bahwa review film 
adalah bentuk praktik bermedia (Maras, 2020).

\section{SIMPULAN}

Berdasarkan apa yang penulis sudah utarakan pada bagian pembahasan, maka dapat diambil kesimpulan bahwa dalam proses Cine Crib sebagai komunitas film dalam mereview film Indonesia. Review film merupakan salah satu positioning dari Cine Crib dimana menjadi produk unggulan ketimbang program lain.

Proses yang ditemukan dalam penelitian ini dibagi menjadi empat kategori, yakni: (1) Tidak ada tema khusus dalam me-review, diberikan kebebasan sesuai ketertarikan masing-masing personal yang me-review; (2) Menentukan siapa yang me-review; (3) Kaidah teoretis yang digunakan Cine Crib dalam mereview film Indonesia; dan (4) Proses editing video untuk saat ini masih dilakukan oleh Aria sendiri, di mana Aria berperan sebagai kurator yang mengkurasi konten yang layak tayang di channel YouTube Cine Crib.

Secara tahapan dan pendekatan, Cine Crib tidak membedakan antara film Indonesia dan dari luar Indonesia, ke Indonesia di sini bukan persoalan metode tetapi lebih pada visi Cine Crib mengangkat berbagai macam film yang diproduksi oleh sineas Indonesia. Bicara film Indonesia dan non Indoneia Cine Crib tidak ada perbedaan secara proses me-review film tersebut.
Dari segi siapa yang me-review, Cine Crib mengedepankan "politik kesempatan" yang sama bagi semua anggota. Semua anggota komunitas memiliki kesempatan yang sama untuk berkembang dan Cine Crib bisa menajdi wadah untuk mengembangkan diri dalam hal mereview film dan hal-hal yang berhubungan dengan kajian film itu sendiri.

Dalam pada konteks Planning, Organizing, Actuating dan Controlling (POAC) George R. Terry adalah bagaimana Cine Crib menyusun sebuah rencana kerja komunitas atau kelompok film, untuk menghasilkan efek yang direncanakan. YouTube sebagai media Cine Crib dalam menyebarluaskan review film, khususnya film Indonesia memberikan sumbangan yang signifikan dalam membangun arena litarsi film. Makan Cine Crib dengan menerapkan POAC meskipun diluar kesadanyanya, berimbas pada popularitas Cine Crib dikenak kalayak sebagai rujukan review film Indonesia.

Sebagai saran, penulis menganjurkan untuk semua anggota komunitas untuk lebih menguasai kajian teoritis dan metodologi dalam mengkaji film, seperti hanya visual literasi. dan mungkin menambah channel untuk membahas sebuah fenomena perfilman khususnya film Indonesia lebih mendalam yang dilihat dari kajian dan metode yang mendalam tetapi dengan pembawaan Cine Crib.

Dengan penelitian ini, penulis berharap 
semakin banyak penelitian terkait kajian film khususnya review dalam bingkai kritik film. Harapannya lahir film-film dan tulisan terkait review dan kritik film yang berkualitas. Kritik dalam konteks ini kritik film dengan salah satu produk review bisa lebih memasyarakat, harapanya insan film bisa lebih memahami kritik sebagai produk kebudayaan yang berjalan bersama dalam meluruskan silang sengkarut medan sosial film dan sekaligus berkontribusi dalam kemajuan film Indonesia.

Dengan semakin besarnya gaung Cine Crib dalam konten review film, maka film indonesia bisa menjadi tuan rumah di negeri sendiri dan juga bersaing di kancah film internasional. Secara keseluruhan kriteria yang digunakan Cine Crib sudah melalui berbagai tahapan, tujuannya untuk memastikan apakah konten yang dibuat sudah layak dinikmati oleh khalayak atau belum, dan yang paling penting adalah apakah sudah sesuai dengan visi Cine Crib dalam me-review film Indonesia.

\section{DAFTAR PUSTAKA}

Alaidrus, F. (2020). Penolakan Kritik Film Termasuk Hal Konyol dan Kekanakkanakan - Tirto.ID. Tirto.Id. https://tirto. $\mathrm{id} /$ penolakan-kritik-film-termasuk-halkonyol-dan-kekanak-kanakan-eq9s

Antelope, S. (2021). Adrian Jonathan Membahas Kritik Film | Blog | Studio Antelope. Studioantelope.Com. https:// studioantelope.com/membahas-kritik-film/
Ardianto, E., Komala, L., \& Karlinah, S. (2007). Komunikasi Massa: Suatu Pengantar. In Simbiosa Rekatama Media (Revisi). Simbiosa Rekatama Media.

Crib, C. (2021). Deskripsi Channel YouTube Cine Crib. Cine Crib. https://www. YouTube.com/c/CineCrib/about

Ernesto, A. (2011). Memetakan Kompleksitas Kajian dan Teori Film, Bagian 1. Cinemapoetica.Com. https:// cinemapoetica.com/memetakankompleksitas-kajian-dan-teori-filmbagian-1/

Feldman, E. B., \& Berleant, A. (1975). Varieties of Visual Experience: Art as Image and Idea. Leonardo, 8(1), 94. https://doi. org/10.2307/1573229

Flinn Sr, J. C. (1941). Film Review: Citizen Kaney. Variety.Com. https:// variety.com/1941/film/reviews/citizenkane-1200413671/

Gardhadipura, A. (2021). Personal Interview. Hakim, N. (2021, March 29). View of Film dan Arah Kebudayaan. Jurnal Imaji. https:// doi.org/https://doi.org/10.52290/i.v12i1.17

Hootsuite. (2021). Social Media Marketing \& Management Dashboard - Hootsuite. Data Internet Indonesia Dan Dunia. https:// www.hootsuite.com/

Insani, T. (2020). IWF 2020: Rasyid "Cine Crib” Bocorkan 5 Hal Ini untuk Reviewer! Idntimes.Com. https://www.idntimes.com/ life/career/tika-insani/rasyid-cine-cribbocorkan-5-hal-ini-untuk-reviewer-c1c2/5 Irwansyah, A. (2009). Seandainya Saya Kritikus Filme (All Editio). Homerian Pustaka.

Irwansyah, A. (2018). Sekilas Sejarah Kritik Film di Indonesia. Watyutink.Com. https:// www.watyutink.com/topik/pikiran-bebas/ Sekilas-Sejarah-Kritik-Film-di-Indonesia Knapp, J. (2013). “Throw That Junk!" The 
Art of the Movie in Citizen Kane. Representations, 122(1), 110-142. https:// doi.org/10.1525/REP.2013.122.1.110

Luthfi, A. (2017). Pendidikan Seni Film dan Televisi Menjadi Penggerak Industri Ekonomi Kreatif. Rekam: Jurnal Fotografi, Televisi, Animasi, 13(2), 99-106. https:// doi.org/10.24821/rekam.V13I2.1933

Macdowell, J., \& Mcculloch, R. (2019). Continuum Journal of Media \& Cultural Studies Introduction: "So bad it's good": aesthetics, reception, and beyond. https:// doi.org/10.1080/10304312.2019.1677978

Maras, S. (2020). Revisiting the distinction between criticism and reviewing: practices, functions, rhetorics, and containers. Https://Doi.Org/10.1080/10304312.2019.1 703902, 34(1), 32-43. https://doi.org/10.1 080/10304312.2019.1703902

Moleong, L. J. (2017). Metodologi penelitian kualitatif(37th ed.).PTRemaja Rosdakarya. Mulyana, D. (2018). Metodologi Penelitian Kualitatif: Paradigma Baru Ilmu Komunikasi dan Ilmu Sosial Lainnya. In Bandung: Remaja Rosda Karya (Edisi Revi). PT Remaja Rosdakarya.

NINGSIH, W. S. R. I. P. (2019). Analisis tahapan mereview film oleh divisi review film komunitas film montase [isi surakarta]. http://repository.isi-ska.ac.id/4652/1/ wahyu sri palupi ningsih.pdf

Pasaribu, A. J. (2011). Francois Truffaut: Mimpi Seorang Kritikus Film, Bagian 1. Cinemapoetica.Com. https:// cinemapoetica.com/francois-truffautmimpi-seorang-kritikus-film-bagian-1/

Permana, R. S. M., Puspitasari, L., \& Indriani, S. S. (2019). Industri film Indonesia dalam perspektif sineas Komunitas Film Sumatera Utara. ProTVF, 3(2), 185. https:// doi.org/10.24198/ptvf.v3i2.23667
Purwoko, H. (2021). View of Humor sebagai Kritik Sosial dalam Zootopia (2016). Jurnal Imaji, 11(Sinema, Ideologi dan Kritik Sosial), 20-26. https://imaji.ikj. ac.id/index.php/IMAJI/article/view/10/8

Ragin, C. C., \& Amoroso, L. M. (2011). Constructing social research: The unity and diversity of method (Third Edit). Pine Forge Press. https://us.sagepub.com/ en-us/nam/constructing-social-research/ book239212\#preview

Rahayu, S. D. (2020). Pengaruh Online Customer Review terhadap Kepercayaan dan dampaknya terhadap Minat Beli film bioskop pada subscribers Channel YouTube Review Film Cine Crib. Tel-U Collection, 20.04.4044, 1-17. https://openlibrary. telkomuniversity.ac.id/pustaka/164598/ pengaruh-online-customer-review-ocrterhadap-kepercayaan-dan-dampaknyaterhadap-minat-beli-film-bioskop-padasubscribers-channel-YouTube-review-film-cine-crib.html

Rakhmat, J., \& Ibrahim, I. S. (2017). Metode penelitian komunikasi (R. K. Soenendar (ed.); Cetakan ke). PT Remaja Rosdakarya. Saputra, S. J. (2017). Ruang keseharian sebagai representasi identitas. Jurnal Kajian Komunikasi, 5(1), 81-90. https://doi. org/10.24198/JKK.V5I1.8706

Selechan, A. T., Oktavia, I., \& Pratiwi, J. (2021). View of Peran Masyarakat Film Indonesia (MFI) Dalam Mendukung Demokratisasi Indonesia (2007-2009). Jurnal Imaji. https://doi.org/https://doi.org/10.52290/i. v12i1.44

Terry, G. R. (2012). Prinsip-prinsip Manajemen ( j Smith; D.F.M. (ed.); Cet. ke-11). 228.

Wahid, U., \& Agustina, S. (2021). Strukturasi proses produksi film horor Pengabdi Setan: Perspektif ekonomi politik. ProTVF, 
5(1), 80. https://doi.org/10.24198/ptvf.

v5i1.25601 